\title{
びまん性特発性骨増殖症に合併した 胸椎腰椎骨折に対する手術療法
}

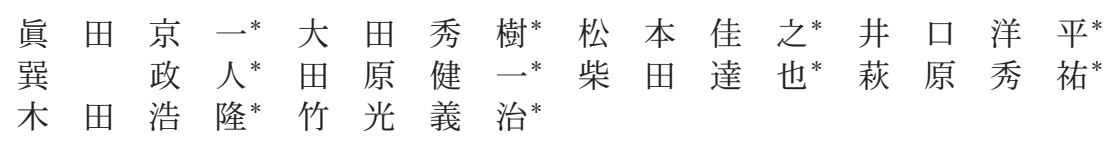

\begin{abstract}
DISH 椎体及びその隣接椎体骨折に対する手術成績を調査した（2015.1～2020.7）。後方固定術は 6 例あ り, DISH 中間部に発生した椎体骨折 4 例, DISH 下位隣接椎体骨折 2 例であった. BKP は 29 例で, DISH 下端椎 3 例，DISH 下位隣接椎体 21 例，下位隣接椎体より以遠椎体 5 例であった．DISH 合併のな い椎体骨折は 68 例であった。後方固定術は全例骨痹合した。BKPに関しては下位端骨折：全例腰痛改善 し隣接椎体骨折は無かった。 DISH 下位隣接椎体：腰痛は 7 例残存，隣接椎体骨折は 6 例，再手術は 1 例 に施行した。 下位隣接以遠椎体：腰痛は 4 例残存，隣接椎体骨折は 1 例, 再手術は 1 例に施行した. DISH 合併のない椎体骨折への BKP は腰痛が 17 例で残存, 隣接椎体骨折は 5 例, 再手術は無かった. DISH 合併例においては骨折部に負荷が加わりやすく，椎体骨折をきたすと骨欠損が大きくなり安定性が 得られにくい.
\end{abstract}

Key words : thoracolumbar vertebral body fracture (胸腰椎椎体骨折), diffuse idiopathic skeletal hyperostosis（びまん性特発性骨增殖症）, balloon kyphoplasty（バルーン椎体形成術）

\section{は じめに}

びまん性特発性骨増殖症（以下 DISH）は胸椎，胸 腰椎部に発生しやすいが, 脊椎の可動性が低下してい るため軽微な外傷にて DISH および DISH 以下の腰 椎部に椎体骨折を生じることがある。診断が遅れると 遅発性麻痺を呈し治療に難渋することがあるので注意 するべき疾患である，また，DISH による可撓性低下 を補うために，その遠位の腰椎は代償性に可動性を増 す必要があり，手術治療成績に影響を与える可能性が ある. 今回は DISH の合併が, 胸椎 . 腰椎椎体骨折の 手術治療成績に与える影響について検討を加えた.

\section{対象および方法}

2015 年 1 月から 2020 年 7 月までに DISH 椎体およ びその隣接椎体骨折に対して手術療法を行った症例を 対象とした. DISH の判定は CT または全脊椎レント ゲンにて，(1)少なくとも 4 椎体以上の前外側面で骨化 を認める, (2)椎間板腔が比較的保たれている, (3)椎間 関節が保たれており，仙腸関節に骨性強直を認めない こととした.
手術治療法は instrument を用いた後方固定術が 6 例（男性 3 例，女性 3 例，年齢は 67 歳から 89 歳，平 均 76.7 歳), バルーン椎体形成術 (BKP) が 29 例（男 性 8 例，女性 21 例，年齢は 66 歳から 91 歳，平均 81.9 歳) であった. 後方固定術 6 例の内訳は DISH 中 間部に発生した椎体骨折 4 例（T9: 1 例, T10: 1 例, $\mathrm{T} 12: 1$ 例, L1 $: 1$ 例), DISH の下位隣接椎体骨折 2 例（T12:2 例）であった. BKPの 29 例の内訳は DISH の下端椎 3 例（T12:1 例, L1 : 2 例 ), DISH の下位隣接椎体 21 例（T7 : 1 例, T10 : 2 例, T11 : 3 例, T12: 2 例, L1 $: 8$ 例, L2 $: 3$ 例, L3 $: 2$ 例), DISH の下位隣接椎体より以遠椎体 5 例（L1:2 例, L2 : 2 例, L3 : 1 例) であった.

更にBKP の治療成績に関しては，同時期に行った DISH 合併のない椎体骨折 68 例に対する BKP の手術 成績を調查し, 両群の比較を行った男性 8 例, 女性 60 例, 年齢は 55 歳から 95 歳, 平均 77.7 歳, $\mathrm{T} 8: 1$ 例, T10:1 例, T11: 3 例, T12: 26 例, L1: 30 例, L2 $: 5$ 例, L3 $: 1$ 例, L5 : 1 例であった.

骨折椎体は側臥位では骨折椎体の cleft は小さいが, 仰卧位にすると大きくなる，その差を骨折椎体不安定

\footnotetext{
* 医療法人一信会大分整形外科病院
} 
度と定義し，以下のような計測を行った，術前側卧位 でのレントゲン側面像における骨折椎体前縁の距離 $\mathrm{A}$ を下縁の距離 B で割った值 X1 とし, 術前仰臥位 での CT 側面像における骨折椎体前縁の距離 C を下 縁の距離 D で割った值 X2 とする.X2/X1 を骨折椎 体不安定度と定義した（図 1)。

数值が高い方が不安定度は大きいことを意味する。 この骨折椎体不安定度をDISH 合併群と非合併群で 比較した.

統計解析は $\chi^{2}$ 検定および student-t 検定を用い, $\mathrm{p}$ $<0.05$ 以下を有意差ありとした.

結果

後方固定術に関しては，最終的には全例に骨癒合を 得たが，1例は骨癒合が遷延した。全例で遺残疼痛は 無かった. 遅発性麻痺を 1 例に認めたが, 術後完全回 復した，BKP に関しては，DISH の下位端骨折は 3 例とも腰痛は改善した。隣接椎体骨折例は無く, 再手 術も無かった. DISH の下位隣接椎体は 21 例中 7 例
（33.3\%）で腰痛が残存し，隣接椎体骨折例を 21 例中 6 例 $(28.6 \%)$ に認めた，再手術を 1 例に要し，セメ ントの前方逸脱のため前方固定術を施行した（図 2). DISH 下位端椎体より以遠椎体は 5 例中 3 例（60\%） で腰痛が残存し,隣接椎体骨折例は 1 例 $(20 \%)$ であつ た. 再手術は 1 例に要し, 後彎位進行による矯正手術 を行った（図 3).

DISH を合併しない椎体骨折への BKP は 68 例中 17 例 $(25 \%)$ で腰痛が残存し, 隣接椎体骨折例は 5 例（7.4\%）に認めたが，再手術例は無かつた（表 1). DISH 合併群，非合併群で比較すると，DISH 合併群 では BKP 後の腰痛残存率は多かったが，有意差は無 かった（ $\chi^{2}$ 検定 $\left.\mathrm{p}=0.20\right)$. また，隣接椎体骨折の発 生率に関しては, DISH 合併群が有意に高いという結 果であった（ $\chi^{2}$ 検定 $\mathrm{p}=0.021 ） （$ 表 $1 ）$.

また, 術前骨折椎体不安定度は DISH 合併群の方 が骨折椎体の不安定度は大きかったが, 有意差は無 かった $(\mathrm{p}=0.16)$.

\section{術前骨折椎体不安定度}

術前の側卧位Xpの骨折椎体前壁の距離/骨折椎体下緑の距離と、術 前の仰卧位CTの骨折椎体前壁の距離/骨折椎体下緑の距離の比

A

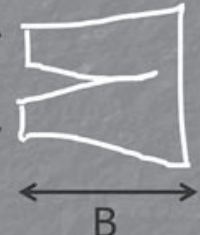

$A / B=X 1$ $C / D=X 2$
C

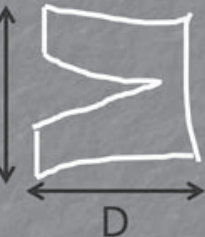

\section{$\frac{X 2}{X 1}=$ 不安定度}

図 1 術前骨折椎体不安定度

表 1 BKP を行った DISH 合併群と非合併の骨折部位別術後成績

\begin{tabular}{lcccc}
\hline \hline & 症例数 & 腰痛 & 隣接骨折 & 再手術 \\
\hline DISH 下端椎体 & 3 & 0 & 0 & 0 \\
DISH 下位隣接椎体 & 21 & 7 & 6 & 1 \\
DISH 下位隣より以遠椎体 & 5 & 3 & 1 & 1 \\
DISH 合併椎体骨折 (合計) & 29 & 11 & 7 & 2 \\
DISH 非合併椎体骨折 & 68 & 17 & 5 & 0 \\
\hline
\end{tabular}




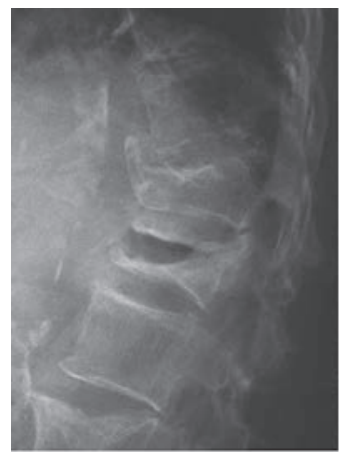

a

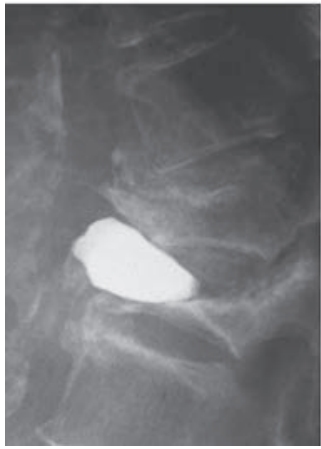

c

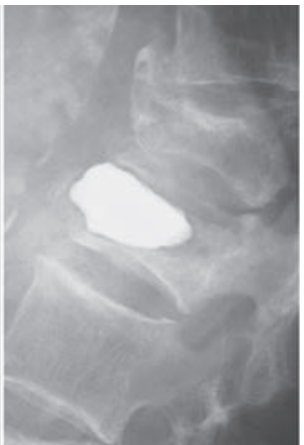

b

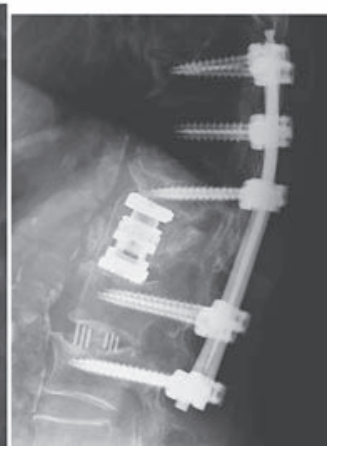

d
図 2 セメントの前方逸脱のため前方固定術を施行し た症例

a BKP 術前, L2 椎体の cleft が大きく, 椎体 不安定性がある.

b BKP 術直後.

c 徐々に骨セメントが前方に逸脱し, 後弯変 形を呈してきた.

d T9-L3 まで経皮的に後方固定した後, L1 椎 体をX-core で置換し, L2/3 はXLIF で椎 体間固定した.
考

察

DISH 範囲内の椎体骨折に対する後方固定術は最終 的には骨癒合が得られ, 臨床成績も良好な成績であつ たが, 一部の症例は骨癒合が遷延化し治療に難航した. DISH 合併の胸腰椎損傷に対し早期の固定を進める報 告は多く ${ }^{3-5)}$, 特に後方要素が破綻している症例は遅 発性麻痺のリスクがあり早期固定術が望ましい2)。軽 微な外傷で発生することが多く, 骨折も初期は目立た ないことがあり，診断が遅れ遅発性麻痺を呈し治療に

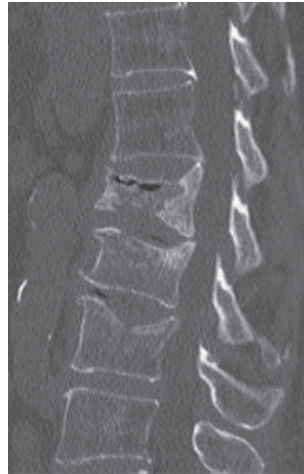

a

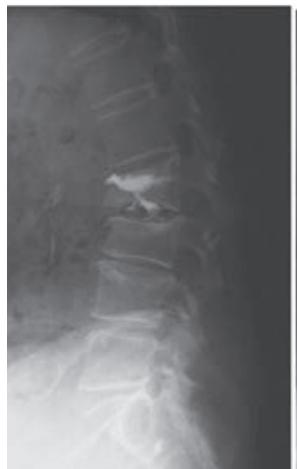

c

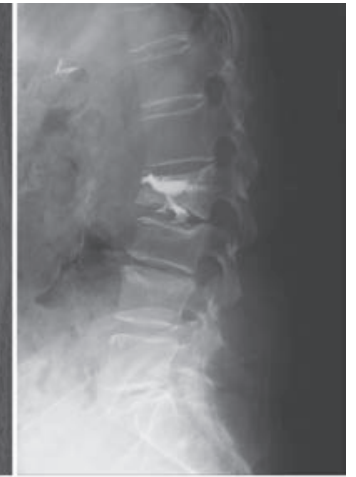

b

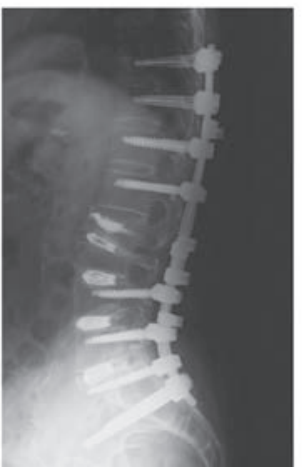

d
図 $3 \mathrm{BKP}$ 後の後弯進行に対し矯正手術を行った症例

a L2 BKP 術前

b BKP 術一週間後

c $\mathrm{BKP}$ 後 1 力月, 春柱後弯が進行し腰痛を訴 えてきた.

d T10 から腸骨まで後方固定し, L2/3 から L5/S1 まで後方椎体間固定術を行い, 症状 は改善した。
難渋することがあるので注意するべき疾患である.

しかし, DISH 患者は高齢者が多く, 糖尿病, 高血 圧，肥満，呼吸機能障害など内科的併存症の有病率が 高( ${ }^{68)}$ とされ，周術期内科的合併症および術後深部 感染などの術後合併症も危惧される. 症例を選べば, より低侵襲な BKP でも良好な成績を得られるという 報告もある ${ }^{27)}$ が，当院においては $28.6 \%$ に腰痛が残 存し，1例はセメントの前方逸脱のため前方固定術を 要しており, 症例の見極めが大切であると思われる.

DISH 合併の胸椎, 腰椎椎体骨折は DISH 下端椎や 
下位隣接椎体が最も多かった．DISH 下位端やその隣 接椎体は，ヒンジ部であり応力集中がおこりやすいた めと考えられる．また，DISH による可撓性低下を補 うために，その遠位にある腰椎は代償性に可動性を増 す必要がある，当院の DISH の下位隣接椎体に対す る BKP は隣接椎体骨折が $33.3 \%$ と多く, やはり後方 固定術を追加する必要性も示唆された.

DISH が手術治療成績に影響を与える可能性があ る. BKP の治療成績に関して言えば，DISH 合併群 では有意差は無いものの腰痛残存率が高く, 隣接椎体 骨折の発生率は有意に DISH 合併群で高く, 再手術 もDISH 合併例にの夕経験した。つまり，DISH を合 併例に対する BKP は腰痛が残存しやすい傾向があり,

隣接椎体骨折も多いと言える.

われわれはその原因を術前の骨折椎体不安定度が DISH 合併群で高いのではないかと推測し, BKP 施 行例において両群を比較した，術前骨折椎体不安定度 は，有意差は無いものの DISH 合併群で骨折椎体の 不安定度は大きかった．DISH 例においてはその下位 の腰椎に多くの負荷が加わるため，一旦椎体骨折をき たすと骨欠損が大きくなり安定性が得られにくい，特 に腹臥位手術では前方骨欠損が増大するため, BKP のような低侵襲手術においても注意を要する.

$$
\text { 結語 }
$$

DISH 範囲内の椎体骨折に対する後方固定術は最終 的には骨瘑合が得られ，臨床成績も良好な成績であつ たが,一部の症例は骨癒合が遷延化し治療に難航した.
DISH 合併例に対する BKP は腰痛が残存しやすい傾 向があり，隣接椎体骨折は有意に多かった。再手術は DISH 合併例にの夕経験した．DISH 合併例において は腰椎に多くの負荷が加わるため, 椎体骨折をきたす と骨欠損が大きくなり安定性が得られにくいため, BKP のような低侵襲手術においても注意を要する.

\section{参 考 文 献}

1）村本明生，松原祐二，森田圭則：びまん性特発性骨粗 鬆症が骨粗鬆症性椎体骨折およびBKP 治療に及ぼす影 響. J. Spine Res., 9(4) : 871-875, 2018.

2) Okada, E., et al.: CT-based morphological analysis of spinal fractures in patients with diffuse idiopathic skeletal hyperostosis. J. Orthop. Sci., 22 : 3-9, 2017

3) Paley, D., et al.: Fracture of the Spine in Diffuse Idiopathic Skeletal Hyperostosis. Clin. Orthop. Relat. Res., 267: 22-32, 1991.

4) 高橋雅也ら : 強直性脊椎骨增殖症の臨床 強直性脊椎骨 增殖症に合併した脊椎・春劬損傷 胸椎および腰椎。春 椎脊髄, $24(3): 197-203,2011$.

5）立川裕一郎ら：強直性春椎骨增殖症の臨床 強直性春椎 骨增殖症における骨折の諸問題一骨折後の偽関節，痋発 性神経麻痺。春椎脊髄，24(3)：211-217, 2011.

6）上井 浩：DISH の臨床 DISH の定義, 分類, 病因. 脊椎脊髄, $32(7): 648-652,2019$.

7）八木秀樹ら：びまん性特発性骨增殖症に伴う椎体骨折 に対する Balloon Kyphoplasty（BKP）の有用性. J Spine Res., 9(4) : 876-880, 2018.

8) 安田剛敏ら：DISH の臨床びまん性特発性骨増殖症 （DISH）に扩ける助椎関節変化と呼吸機能の関連. 春椎 春髄, 32 (7)：661-666, 2019. 